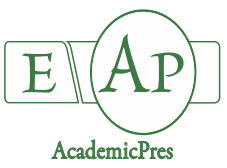

Tu M et al. (2020)

Notulae Botanicae Horti Agrobotanici Cluj-Napoca 48(2):509-522

DOI: $10.15835 /$ nbha48211659

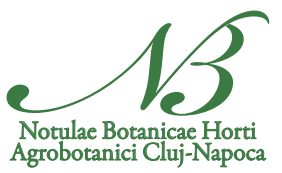

\title{
Development of SCAR markers related to heat tolerance in Kentucky bluegrass
}

\author{
Mingyue $\mathrm{TU}^{1}$, Yali $\mathrm{HE}^{2}$, Xiaoli $\mathrm{LI}^{1}$, Ying $\mathrm{ZOU}^{1}$, Xiaojun YUAN ${ }^{1 *}$ \\ ${ }^{1}$ Shanghai University, School of Life Science, Shanghai Key Laboratory of Bio-Energy Crops, Shanghai 200444, China; \\ m18817510336@163.com;1953269026@qq.com;1329276761@qq.com; yuanxiaojun@shu.edu.cn(*correspondingauthor) \\ ${ }^{2}$ Shanghai Jiaotong University, School of Agriculture and Biology, Shanghai 200240, China; heyali@sjtu.edu.cn
}

\begin{abstract}
As a high-quality cool-season grass, Kentucky bluegrass (Poa pratensis) is facing increasing threat of high temperature, so improving its heat tolerance (HT) has become an important breeding target. In this study, the HT of 84 materials was identified in the artificial climate chamber, and 15 most heat-tolerant and 15 most heat-sensitive materials were selected respectively to construct two DNA pools. There was a significant difference in high-temperature tolerance time between the plants in the two pools, which was more than 22 days. A total of 304 sequence-related amplified polymorphism (SRAP) and 88 simple sequence repeat (SSR) markers were used to screen the polymorphic bands between the two pools. Then, these bands were transformed into sequence characterized amplified region (SCAR) markers, and finally 12 SCAR dominant markers related to HT were obtained, which could detect the heat-sensitive materials efficiently. Among them, S-me8 8 em 2 and S-me $52 \times e m 5$ had the best identification effect, and the consistency between the absence of these two markers and the heat-sensitive phenotype was $87 \%$. According to the comparison with NCBI database, the sequences of 12 SCAR markers had no homology with known HT related genes. Next, we would further verify the HT identification efficiency of these SCAR markers in single plants within materials, and try to use them in molecular marker-assisted breeding.
\end{abstract}

Keywords: heat tolerance; Poa pratensis; SCAR marker; SRAP marker; SSR marker

\section{Introduction}

Kentucky bluegrass (Poa pratensis) (KBG) is a cool-season turfgrass, which is widely distributed in temperate and cold regions of the world (Gan et al., 2016). Due to its soft texture and excellent resilience, it is often used for greening and various sports venues. As global warming continues, elevated temperature is increasingly threatening the growth of cold-season grasses. High temperature will affect plant photosynthesis, respiration, water balance, and destroy the stability of leaf membrane, thereby accelerating plant aging, shortening growth cycle, and ultimately affecting yield. Global surface temperature has risen by $0.5^{\circ} \mathrm{C}$ in the past century, and is expected to continue rising by $1.5-4.5^{\circ} \mathrm{C}$ in the 21 st century (Karl et al., 1991; Hansen et al., 2006). In China, high temperature is common throughout the country in summer. For example, in the middle and lower reaches of the Yangtze river, the temperature in July and August is generally $25-35^{\circ} \mathrm{C}$, and 
extreme temperature above $40{ }^{\circ} \mathrm{C}$ often occur. High temperature seriously restricted the development and utilization of KBG in these areas. Therefore, improving plant heat tolerance (HT) and discovering the HT related genes are important breeding target and research direction in KBG.

The genetic background and reproductive pattern of KBG are extremely complex. They can produce seeds both sexually and asexually (apomixis), and a complex series of polyploidy and aneuploidy often exists among different strains. Moreover, HT is a complex trait controlled by multiple genes, involving many regulatory mechanisms in plants. Therefore, it is difficult to study the HT of KBG by conventional molecular biology methods like model plants. In addition, conventional turfgrass breeding (e.g., ecotype selection, artificial hybridization) for HT should take a lot of time and labour. New cultivar development in KBG takes at least 6 years, but is usually closer to 8 to 10 years after seed production and turf plot evaluation (Meyer $e t$ al., 2017).

Facing the complex genetic background and target trait, it may be an efficient and feasible approach to study HT by molecular markers, such as screening molecular markers linked to HT genes for marker-assisted breeding. With the development of molecular marker technology, it has become an important means of plant research and is widely used in various important crops. Currently, commonly used molecular markers include random amplified polymorphic DNA (RAPD) (Williams et al., 1990), amplified fragment length polymorphism (AFLP) (Vos et al., 1995), sequence-related amplified polymorphism (SRAP) (Li and Quiros, 2001), simple sequence repeat (SSR) (Akkaya et al., 1992), sequence characterized amplified region (SCAR) (Paran and Michelmore, 1993) and so on.

According to the design principle of primers, SRAP markers can produce polymorphic amplification products due to the differences in the introns, promoters and spacer regions between different individuals. In SSR markers, primers are designed to amplify repeat sequences by using the conservative sequences on both sides of tandem repeat short sequences, so as to detect polymorphisms caused by different sequence repeat times. Because these two types of markers have the advantages of simple operation, high polymorphism and reliable results, they have been widely used in genetic map construction, genetic diversity analysis, species identification, and gene localization of important agronomic traits in various grasses, such as buffalograss (Buchloe dactyloides), bermudagrass (Cynodon dactylon), sainfoin (Onobrychis viciifolia), Hemarthria compressa, Trichloris crinita, sage (Salvia), bentgrass (Agrostis) etc. (Budak et al., 2004a; Budak et al., 2004b; Wang et al., 2011; Huang et al., 2012; Honig et al., 2016; Aghaei et al., 2017; Zheng et al., 2017; Guo et al., 2017; Kempf et al., 2017; Kozub et al., 2018).

SSR and SRAP markers also play important roles in abiotic stress studies of crops. For example, in wheat (Triticum aestivum), Moustafa et al. (2014) identified SRAP markers linked with six agronomic traits under drought stress. Said et al. (2015) detected SRAP markers associated with four agronomic traits related to HT. El-Rawy and Youssef (2014) evaluated the drought and HT in wheat based on seedling traits, and screened the SRAP markers associated with them. In rice (Oryza sativa), salt tolerance could be evaluated by $\mathrm{K}^{+} / \mathrm{Na}^{+}$ratio, so Reddy et al. (2017) identified five SSR markers linked to the ratio, which could help in differentiation of tolerance at the seedling stage. Molla et al. (2015) identified SSR markers from salt responsive candidate genes and used them as a remarkable tool to distinguish slat sensitive and tolerant rice genotypes. In addition, Huang et al. (2017) screened out three SSR markers that were highly positively correlated with relative conductivity and malondialdehyde content, which could distinguish the cold-resistant and non-coldresistant varieties in Brassica rapa.

In recent years, the search for molecular markers related to abiotic stress resistance has also been carried out in turfgrass. For example, 2 SSR markers associated with growth rate and evapotranspiration rate were simultaneously identified in two tall fescue (Festuca arundinacea) trials in response to heat stress (Sun et al., 2015a). In creeping bentgrass (Agrostis stolonifera), Jespersen et al. (2018) identified 21 SSR markers and 3 candidate gene markers associated with either summer performance or drought tolerance. However, in general, the application of molecular markers in abiotic stress research and breeding in turfgrass is very limited. 
This study was designed to identify SRAP and SSR markers that are linked to HT trait via pseudobulked segregant analysis (BSA) method. Then, these markers would be further transformed into SCAR markers and verified in the HT identification population. The objective of the study is to find more molecular markers related to HT for future molecular marker-assisted breeding to improve breeding efficiency. At the same time, we hope to learn more information about the HT genes in KBG.

\section{Materials and Methods}

\section{Plant materials}

In this study, a total of 84 KBG materials (J1-J84) from home and abroad were collected for HT identification and molecular marker polymorphism screening. Subsequently, 5 more materials (X1-X5) were collected, together with the previous 84 materials, for the PCR amplification of SCAR markers. All 89 materials (Table S1) included 50 imported varieties, 12 wild materials abroad, 5 domestic varieties/lines, and 22 domestic wild materials. Seventy-three of these materials (Z1-Z73) had previously been analysed for genetic diversity using SSR and SRAP markers (Yuan et al., 2018).

On October 12, 2015, seeds of all materials were taken for germination. One month later, 12 seedlings of each material were randomly selected and transplanted to potted trays. These plants were grown in a farm greenhouse at the School of Agriculture and Biology, Shanghai Jiaotong University, Shanghai, China, for HT identification. Since some materials failed to recover after heat stress, all materials (except for J23 and J25, no seeds) were reseeded for germination by the end of September 2017, for later use in SCAR markers verification. They were also cultured in the greenhouse under natural conditions (about $15-30{ }^{\circ} \mathrm{C}, 40-80 \%$ humidity, and natural sunlight).

\section{HT identification}

This experiment adopted completely random block design. There were 2 blocks, each block included 84 materials, and each material was planted in a row ( 6 plants). All these plants were transferred to the artificial climate chamber on July 12,2016 controlled at $25^{\circ} \mathrm{C} / 20^{\circ} \mathrm{C}$ ( $16 \mathrm{~h}$ day $/ 8 \mathrm{~h}$ night). A week later, the plants were pruned to about $6-7 \mathrm{~cm}$ tall. After another 3 days, heat stress began, and the temperature was adjusted to $40^{\circ} \mathrm{C}$ $135^{\circ} \mathrm{C}$ (16h day /8h night). In order to expose each plant to the same degree of stress as possible, moved the trays clockwise (about two weeks in a cycle) and inverted each tray $180^{\circ}$ every day. During the whole experiment, the daylight intensity of the artificial climate chamber was 600Lux and the humidity was $50 \%$. Plants were watered every two days, evenly watering each tray for $2 \mathrm{~L}$.

Plant height of each individual was measured at four time points: before normal temperature culture (BN), one week after normal temperature culture $(\mathrm{AN})$, before heat stress $(\mathrm{BH})$, and one week after heat stress $(\mathrm{AH})$. Then, the growth rate under heat stress $(\mathrm{GRH})$ was calculated: [plant height $(\mathrm{AH})$ - plant height $(\mathrm{BH})$ ] / [plant height $(\mathrm{AN})$ - plant height $(\mathrm{BN})] \times 100 \%$.

After 7 days of high temperature stress (July 29), the individuals with the worst performance were taken out for the first time, and then a batch of individuals with the worst state for the day were taken out every other day. Extraction criteria for these plants were: at least half leaf area was wilted and yellow. Also, all the plants taken out on the same day were ranked from poor to good, and then put into the light incubator at $20^{\circ} \mathrm{C}$ for restoration culture. Combined with the date of extraction and the state ranking of the day, the HT of each plant was calculated according to the following formula:

$$
\text { HT score }=D+\frac{1}{N} \times(A-1)
$$

Where, 'D' was the D time to take out (July 29 is the first time, that is $\mathrm{D}=1$ ); ' $\mathrm{N}$ ' was the total number of plants taken out that day; 'A' was the state ranking of the single plant taken out on that day (the worst one, $A=1)$. The higher the HT score, the better HT of the plant. 
The HT of each material was based on the average score of 12 individual plants in the material, and the HT of 84 materials was then ranked from strong to weak. From the materials recovered after stress, 15 most heat-tolerant and 15 most heat-sensitive materials were selected respectively. Next, chose the most extreme plant from each material. For example, chose the most heat-tolerant plant from the tolerant material, the most heat-sensitive plant from the sensitive material, and if the plant died, chose the second most sensitive plant, and so on. In this way, 15 heat-tolerant and 15 heat-sensitive plants were selected respectively for subsequent polymorphic screening of molecular markers.

\section{DNA extraction and polymorphic screening of molecular markers}

The fresh leaves of each plant were collected and frozen in liquid nitrogen for subsequent extraction of genomic DNA with CTAB method (Clark, 1998). Equal amounts of DNA from 15 heat-tolerant plants and 15 heat-sensitive plants were pooled to construct two DNA pools, heat-tolerant pool (HTP) and heat-sensitive pool (HSP). In addition, identical amounts of leaves were collected from about 20 reseeded plants in each material, and the DNA mixture of each material was extracted for SCAR verification. All extracted DNA samples were detected by $0.8 \%$ agarose gels via electrophoresis.

A total of 304 SRAP and 88 SSR primer pairs were selected for polymorphism screening, which had good amplification effect in previous studies. The primers of SSR markers were from Honig et al. (2010). The SRAP markers used in this study were chosen from Li and Quiros (2001), Ferriol et al. (2003), Li et al. (2003) and Wang et al. (2005) (Table S2). All the primers were synthesized by Sangon Biological Engineering Technology and Service Co. Ltd, Shanghai. The PCR reaction system and amplification procedure of SRAP and SSR markers were carried out according to Yuan et al. (2018). All PCR reactions were confirmed at least twice.

Initially, BSA was used to screen the polymorphic bands between the two DNA pools, but no ideal difference bands (HTP: with bands; HSP: no band) were found. Then, the DNA of 30 individual plants was amplified directly, and the bands that were present in most heat-tolerant individual plants and absent in most sensitive individual plants were selected. To avoid omission, looser selection criterion was set: if the total number of bands amplified in [(HTP's plants) - (HSP's plants)] $\geq 8$, the bands were recorded. Subsequently, polymorphic bands were scored as present (1) or absent (0); meanwhile, heat tolerance and sensitivity of the plants were recorded as 1 and 0 respectively. The data were analysed using the Numerical Taxonomy and Multivariate Analysis System (NTSYSpc) version 2.10 (Exeter Software, Setauket, NY). Based on the dendrogram constructed by the unweighted pair group method (UPGMA), the polymorphic bands closely related to HT were found.

\section{Cloning and sequencing of the fragments related to $H T$}

Cut the polyacrylamide gel with the target band and dissolved it in the double distilled water. After centrifugation, $4 \mu \mathrm{L}$ supernatant was used as template for PCR amplification. The reaction conditions were as follows: $95^{\circ} \mathrm{C}$ for $3 \mathrm{~min}$, followed by 35 cycles of $95^{\circ} \mathrm{C} 15 \mathrm{~s}, 50{ }^{\circ} \mathrm{C} 30 \mathrm{~s}$ and $72{ }^{\circ} \mathrm{C} 30 \mathrm{~s}$, and a final extension at $72{ }^{\circ} \mathrm{C}$ for $6 \mathrm{~min}$. The amplification products were separated on $1.0 \%$ agarose gels and retrieved with the Gel Extraction Kit (DV805A, TaKaRa, Talien, China). The target bands were ligated into the pMD18-T vector (D101A, TaKaRa, Talien, China). The positive clones bearing DNA of the expected size were sequenced by Sangon Biotech (Shanghai, China).

\section{SCAR primer design and amplification}

According to the sequence of the fragments, Primer Premier 5.0 software was used to design the SCAR primers (primer length $\geq 21 \mathrm{bp}$ ). SCAR markers were named as "S-" + "SSR/SRAP marker name". The condition of the SCAR amplification was as follows: $94^{\circ} \mathrm{C}$ for $3 \mathrm{~min}$, followed by 30 cycles at $94^{\circ} \mathrm{C}$ for $10 \mathrm{~s}$, annealing for $30 \mathrm{~s}$, and $72{ }^{\circ} \mathrm{C}$ for $30 \mathrm{~s}$ and a final extension at $72{ }^{\circ} \mathrm{C}$ for $6 \mathrm{~min}$. Annealing temperature of different SCAR markers were $55-62^{\circ} \mathrm{C}$. 


\section{Results}

\section{Identification of $H T$ in $K B G$ materials}

The top three HT materials were J10 (imported variety), J84 (wild material abroad) and J06 (imported variety). Their HT scores were all over 22 points, which meant that they did not show serious stress state until 49 days after thermal stress. There were 19 materials with more than 19 points, among which 14 were imported varieties, 1 was domestic variety, and 4 were wild materials from home and abroad. The three materials with the lowest HT scores were J64, J51 and J46, which were all wild materials in China. All of them scored less than 5 points, suggesting that they were significantly worse off after 15 days of heat stress. A total of 18 materials scored less than 14 points, except J22, the rest were all wild materials (13 domestic and 4 foreign). Comparing the top three and the bottom three materials, the tolerance time to stress was more than one month different, indicating that there was a significant difference in HT between them. As a whole, the HT of imported varieties was better than that of wild materials.

According to the material's HT score and the individual plant's HT score in the material, 15 plants with the strongest and weakest HT were selected from the recovered plants respectively (Table 1) for subsequent polymorphism screening. Among them, all the heat-tolerant individual plants scored more than 22 points, and their materials scored more than 19 points. All the heat-sensitive individual plants scored less than 11 points, and their materials scored less than 15 points. The tolerance time of the individual plants between the two pools was more than 22 days.

Table 1. Heat tolerance ranking and score of the materials constituting the heat-tolerant and heat-sensitive pools $^{1}$

\begin{tabular}{|c|c|c|c|c|c|c|c|}
\hline Code & $\begin{array}{c}\text { HT } \\
\text { ranking }^{2}\end{array}$ & $\begin{array}{c}\text { HT } \\
\text { score }^{2}\end{array}$ & $\begin{array}{c}\text { GRH } \\
(\%)\end{array}$ & Code & $\begin{array}{c}\text { HT } \\
\text { ranking }^{2}\end{array}$ & $\begin{array}{c}\text { HT } \\
\text { score }^{2}\end{array}$ & $\begin{array}{c}\text { GRH }^{3} \\
(\%)\end{array}$ \\
\hline J10 & 1 & 22.90 & 13.04 & J46 & 82 & 4.81 & 20.21 \\
\hline J84 & 2 & 22.19 & 37.43 & J72 & 81 & 5.55 & 21.54 \\
\hline J06 & 3 & 22.05 & 12.67 & J69 & 80 & 6.04 & 28.44 \\
\hline J11 & 4 & 21.75 & 17.27 & J70 & 79 & 6.96 & 20.72 \\
\hline J83 & 5 & 20.99 & 19.40 & J53 & 78 & 7.33 & 28.98 \\
\hline J01 & 7 & 20.33 & 39.72 & J48 & 77 & 8.03 & 23.23 \\
\hline J41 & 8 & 20.32 & 39.01 & J71 & 76 & 8.92 & 23.30 \\
\hline J27 & 11 & 19.58 & 32.42 & J52 & 75 & 9.25 & 23.95 \\
\hline J62 & 12 & 19.40 & 44.40 & J49 & 74 & 10.25 & 29.77 \\
\hline J39 & 13 & 19.32 & 33.27 & J781 & 73 & 11.05 & 27.27 \\
\hline J12 & 14 & 19.30 & 16.91 & J74 & 72 & 12.18 & 51.40 \\
\hline J02 & 15 & 19.21 & 30.04 & J80 & 69 & 13.23 & 26.30 \\
\hline J42 & 16 & 19.14 & 62.15 & J79 & 68 & 13.61 & 36.20 \\
\hline J07 & 17 & 19.12 & 20.22 & J22 & 67 & 13.81 & 40.09 \\
\hline J35 & 18 & 19.11 & 34.72 & J04 & 66 & 14.57 & 18.02 \\
\hline
\end{tabular}

${ }^{1}$ The left half of the table is the materials used to build heat-tolerant pool, the right half of the table is the materials constituting the heat-sensitive pool.

${ }^{2} \mathrm{HT}$, heat tolerance; both score and ranking refer to the average performance of the material.

${ }^{3} \mathrm{GRH}$, growth rate under heat stress

\section{Growth rate under thermal stress}

After heat stress, the growth rate of all materials slowed down significantly, and the slowing degree of different materials was obviously different. For example, in the first heat stress week, the GRH of J42 could still reach $62 \%$, and the GRH of J68, J45, J31 and J74 could also reach more than $50 \%$. However, some other 
materials showed severe growth inhibition after stress, such as J06, J10, J13, J14, J15, J16, J51, J64 and J66, whose growth amount in the first heat stress week were less than $15 \%$ of normal temperature. Further analysis showed that there was no correlation between HT ranking and GRH among these most heat-tolerant and sensitive materials (Table 1). In the HTP, some materials were severely inhibited by high temperature (J06, $\mathrm{J} 10$ ), while others were less affected (J42). Therefore, the HT of the material could not be judged simply by its GRH.

\section{Screening for molecular markers related to heat resistance}

Between the heat tolerant and sensitive materials, SRAP and SSR markers showed high polymorphism, with a total of 1254 SRAP and 77 SSR polymorphism bands (Figure 1). If the presence or absence of bands were identical in these 30 plants, then these bands were classified into one type. After classification, there were 373 types of SRAP bands, denoted as SRAP-1 SRAP-373, and 36 types of SSR bands, denoted as SSR-1 SSR36. Cluster analysis $(15+15)$ of these band types and HT trait was then performed.
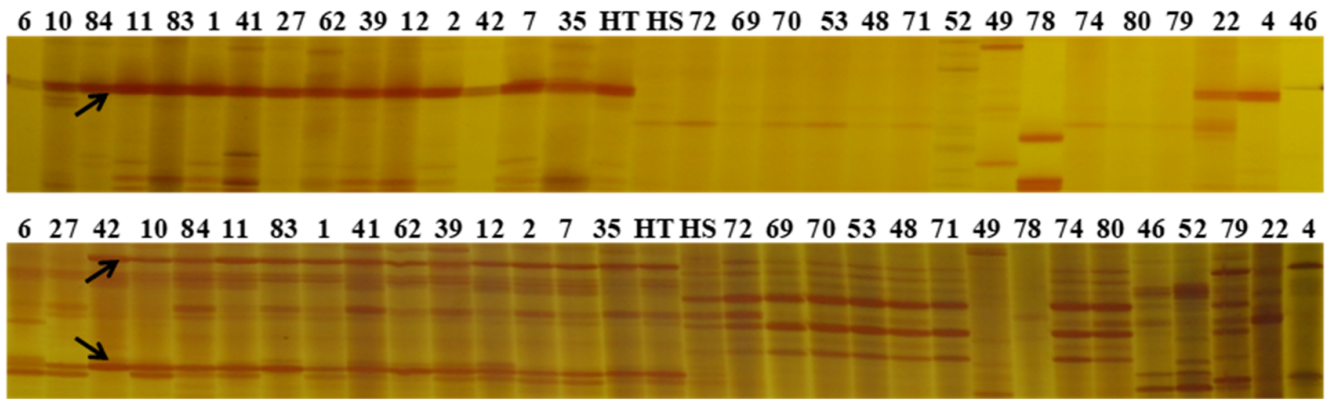

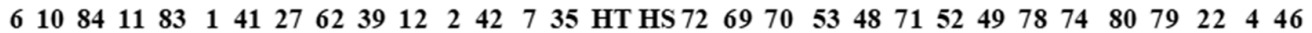

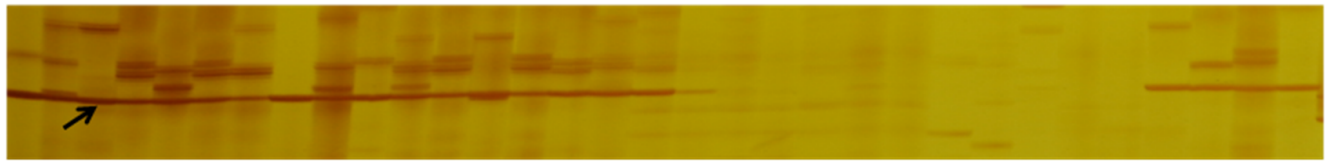

$\begin{array}{lllllllllllllllllllllllllllllll}6 & 10 & 84 & 11 & 83 & 1 & 41 & 27 & 62 & 39 & 12 & 2 & 42 & 7 & 35 & \text { HT HS } & 72 & 69 & 70 & 53 & 48 & 71 & 52 & 49 & 78 & 74 & 80 & 79 & 22 & 4 & 46\end{array}$

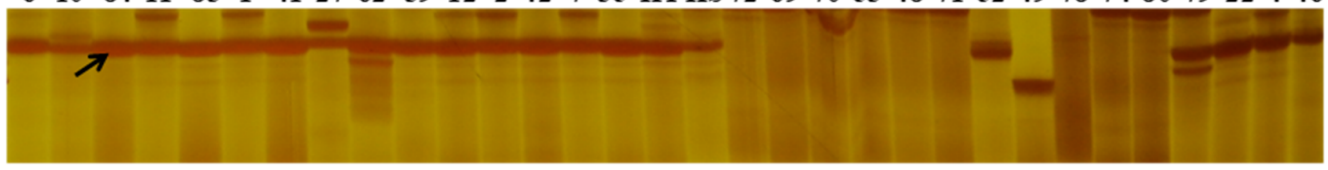

Figure 1. Polymorphism screening of SRAP and SSR primers in two pools and 30 plants that comprising the two pools. Primers from top to bottom are me $4 \times \mathrm{em} 9$ (SRAP), PM8 $\times$ em10 (SRAP), GA1 (SSR), and GA753 (SSR); HT, heat-tolerant pool; HS, heat-sensitive pool; Arrows indicate the polymorphic bands

In the statistical process, it was found that the amplification results of some plants were sometimes different from others in the same pool, such as J06, J27, J42, J79, J22, and J04. Then, these individual plants were removed and the remaining 12 heat-tolerant and 12 heat-sensitive plants were analysed again. The SRAP bands were merged into 186 types and the SSR bands into 31 types. Cluster analysis $(12+12)$ was used to find the band types with high correlation with HT trait (Figure S1). Based on the results of cluster analysis $(12+12)$ and referring to the results of cluster analysis $(15+15), 29$ SRAP bands and 2 SSR bands were selected finally. These fragments were present in most heat-tolerant plants and absent in most heat-sensitive plants.

\section{Development and validation of SCAR markers}

Of the 31 bands (29 SRAP+2 SSR) mentioned above, 24 were sequenced successfully, most of which were between 200-600 bp in size. According to their sequences, 24 pairs of primers were designed, and these 
SCAR primers were amplified in the 30 plants of the two pools (Figure 2). By comparison, the amplification results of 19 SCAR markers were consistent with the original SRAP/SSR markers, and then these SCAR markers were further amplified in 82 materials that had been previously tested for HT (Figure 3). Finally, 14 SCAR markers were obtained that could amplify the stable clear specific bands in the population (Table 2).

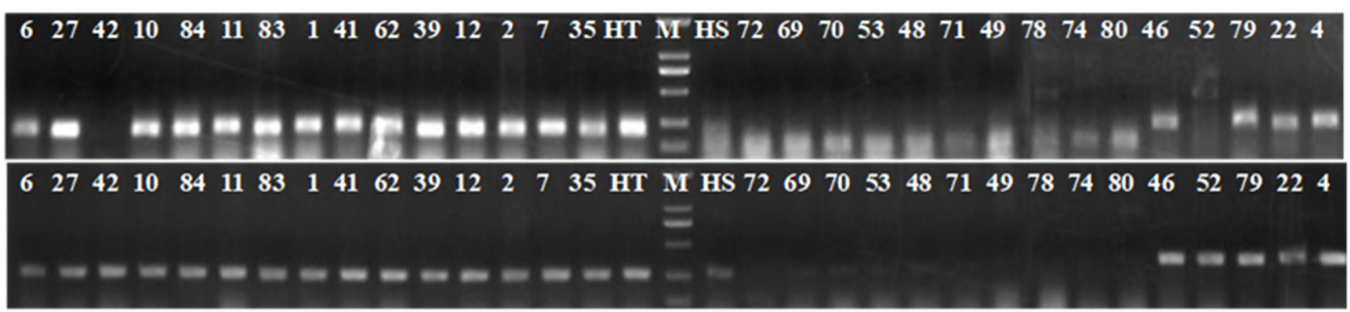

Figure 2. Polymorphism screening of SCAR primers in two pools and 30 plants that comprising the two pools. Primers from top to bottom are S-GA1 and S-me22×em18; HT, heat-tolerant pool; HS, heatsensitive pool; M, DNA Marker DM2000 (CWBIO, China)

A)

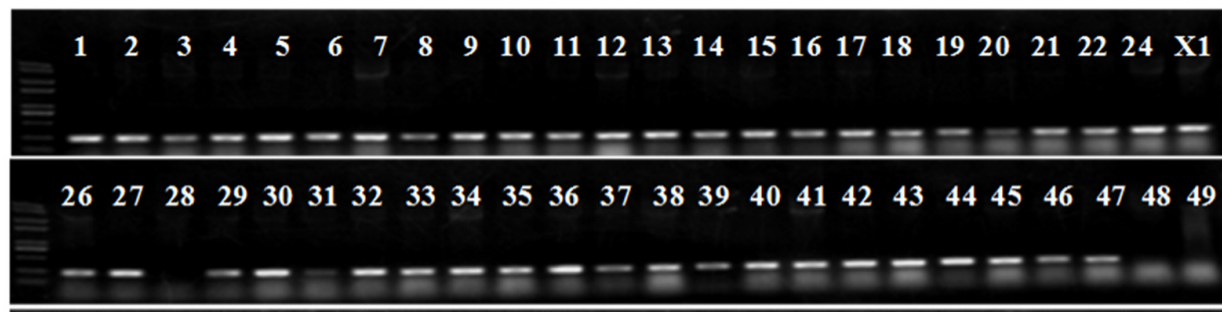

$\begin{array}{llllllllllllllllllllllll}50 & 51 & 52 & X 2 & X 3 & 53 & 54 & 55 & 56 & 57 & 58 & 59 & 60 & 61 & 62 & 63 & 64 & 65 & 66 & 67 & 68 & 69 & 70 & 71\end{array}$

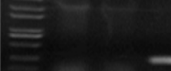

$--\infty-\infty-1$

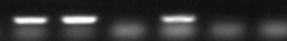

$\begin{array}{llllllllll}72 & 73 & 75 & 76 & 78 & 79 & 80 & 81828384 \times 4 \times 5\end{array}$

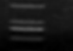

$--\infty-\infty-\infty-\cdots$

B)

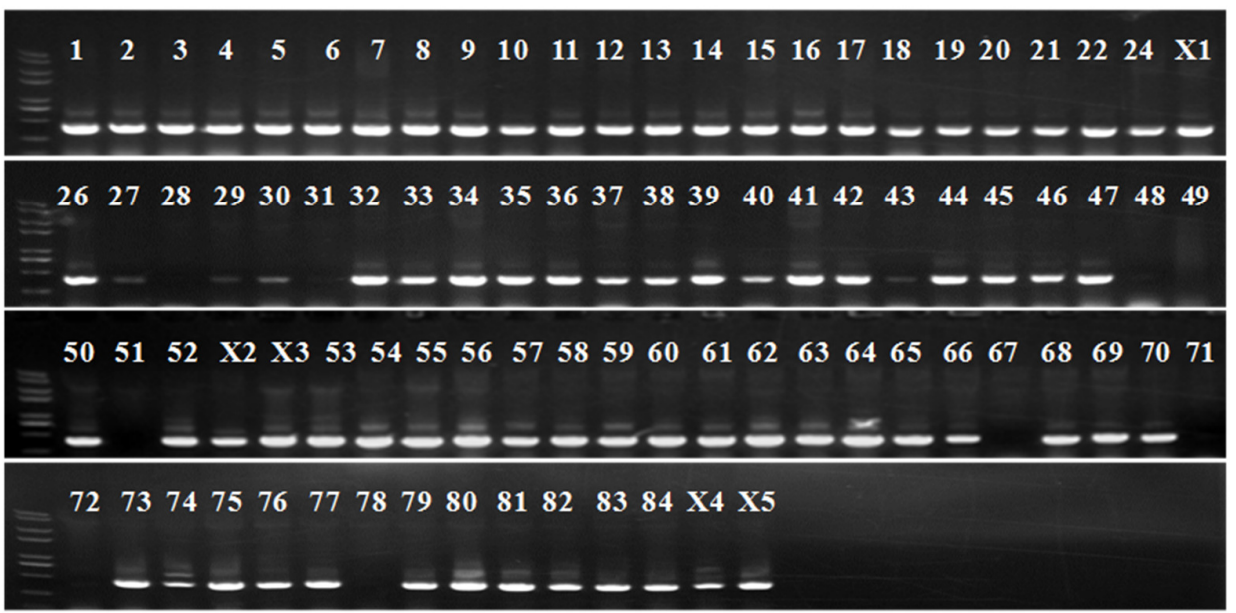

Figure 3. Amplification bands of 87 Kentucky bluegrass materials generated by SCAR markers. (A) The SCAR primer combination S-me52×em5; (B) The SCAR primer combination S-PM8×em 10 
Tu M et al. (2020). Not Bot Horti Agrobo 48(2):509-522

Table 2. 14 SCAR primer pairs derived from the cloned SRAP and SSR markers

\begin{tabular}{|c|c|c|c|}
\hline SCAR name & Primer sequence $\left(5^{\prime}->3^{\prime}\right)^{1}$ & $\begin{array}{l}\text { Annealing } \\
\text { temp }\left({ }^{\circ} \mathrm{C}\right)\end{array}$ & $\begin{array}{c}\text { Amplicon size } \\
\left(\mathrm{bp}^{2}\right)\end{array}$ \\
\hline \multirow{2}{*}{ S-me $2 \times \mathrm{em} 9$} & F: TGAGTCCAAACCGGAGCAGGA & \multirow{2}{*}{56} & \multirow{2}{*}{397} \\
\hline & R: GACTGCGTACGAATTTCACACATATAAT & & \\
\hline \multirow{2}{*}{ S-me $4 \times \mathrm{em} 4$} & F: TGAGTCCAAACCGGACCTGCA & \multirow{2}{*}{59} & \multirow{2}{*}{341} \\
\hline & R: GACTGCGTACGAATTTGACCAGTTT & & \\
\hline \multirow{2}{*}{ S-me $4 \times$ em 9} & F: TGAGTCCAAACCGGACCGTGGTAT & \multirow{2}{*}{55} & \multirow{2}{*}{300} \\
\hline & R: GACTGCGTACGAATTTCATCATTGT & & \\
\hline \multirow{2}{*}{ S-me $5 \times \mathrm{em} 51$} & F: TGAGTCCAAACCGGAAGTGTAGAT & \multirow{2}{*}{55} & \multirow{2}{*}{267} \\
\hline & R: GACTGCGTACGAATTGATTGATGTT & & \\
\hline \multirow{2}{*}{ S-me7xem6 } & F: TGAGTCCAAACCGGTGCCATCTA & \multirow{2}{*}{55} & \multirow{2}{*}{345} \\
\hline & R: GACTGCGTACGAATTGCATGTAAAAAG & & \\
\hline \multirow{2}{*}{ S-me7xem7 } & F: TGAGTCCAAACCGGTGCAGAGTA & \multirow{2}{*}{55} & \multirow{2}{*}{216} \\
\hline & R: GACTGCGTACGAATTCAAGGAGAAG & & \\
\hline \multirow{2}{*}{ S-me $8 \times \mathrm{em} 2$} & F: TGAGTCCAAACCGGTAGACATC & \multirow{2}{*}{55} & \multirow{2}{*}{368} \\
\hline & R: GACTGCGTACGAATTTGCCATC & & \\
\hline \multirow{2}{*}{ S-me9×GA18 } & F: TGAGTCCAAACCGGCAGGAGAA & \multirow{2}{*}{56} & \multirow{2}{*}{606} \\
\hline & R: GGCTTGAACGAGTGACTGAACCTT & & \\
\hline \multirow{2}{*}{ S-me10×em9 } & F: TGAGTCCAAACCGGCATCGAC & \multirow{2}{*}{55} & \multirow{2}{*}{368} \\
\hline & R: GACTGCGTACGAATTTCACCTCTG & & \\
\hline \multirow{2}{*}{ S-me $22 \times e m 18$} & F: TGAGTCGTATCCGGAGTGATAACAG & \multirow{2}{*}{55} & \multirow{2}{*}{265} \\
\hline & R: GACTGCGTACGAATTCCTTTGCC & & \\
\hline \multirow{2}{*}{ S-me23×GA18 } & F: TGAGTCGTATCCGGTAGAATCAGC & \multirow{2}{*}{58} & \multirow{2}{*}{347} \\
\hline & R: GGCTTGAACGAGTGACTGACTG & & \\
\hline S-me52xem 5 & F: TGAGTCCTTTCCGGTAACAGAGC & 55 & 244 \\
\hline $3-m e s<x e m$ & R: GACTGCGTACGAATTAACAGTATTC & ) & 244 \\
\hline S_PM 8xem 10 & F: CTGGTGAATGCCGCTCTCGATC & 62 & 387 \\
\hline 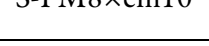 & R: GACTGCGTACGAATTGAGGGCAA & 02 & 507 \\
\hline$S-G$ & F: AAGGCTCGGTTGAGTTCAGTGAGG & 5 & 201 \\
\hline 3-une & R: TTTGGAAGAGGAGGCAGAGAAGTG & ) & 201 \\
\hline
\end{tabular}

${ }^{1} \mathrm{~F}$, forward primer; $\mathrm{R}$, reverse primer

${ }^{2} \mathrm{bp}$, base pair

According to the HT ranking of 84 materials, three sections of materials were selected (10 materials in each section): heat-tolerant group [1st-11 th, except J23 (6th)], medium group [38th-48th, except J25 (44th)], and heat-sensitive group (75th-84th). The total number of bands amplified by each SCAR marker in 10 materials per section was calculated (Table 3). 14 SCAR markers amplified an average of 9.6, 8.3 and 4.4 bands in heat-tolerant, medium and heat-sensitive group respectively. Unexpected, there was no significant band reduction in the medium group compared with the heat-tolerant group. In the sensitive group, the markers with the least bands were S-me $8 \times e \mathrm{~m} 2$ and S-me $2 \times \mathrm{em} 5$ ( 2 bands), followed by S-me $22 \times e m 18$ and S-GA1 (3 bands). Except for S-me4xem 4 and $S$-me $7 \times e m 7$, the number of bands amplified by the other 12 SCAR markers in the three groups showed a tendency of gradually decreasing with the decrease of HT. 
Table 3. The number of bands amplified by 14 SCAR markers in heat tolerant, medium and sensitive groups $^{1}$

\begin{tabular}{|c|c|c|c|}
\hline \multirow{2}{*}{ SCAR name } & \multicolumn{3}{|c|}{ The number of amplified bands } \\
\hline & Heat-tolerant group & Medium group & Heat-sensitive group \\
\hline S-me $2 \times e m 9$ & 10 & 7 & 4 \\
\hline S-me $4 \times$ em 4 & 10 & 7 & 9 \\
\hline S-me $4 \times$ em 9 & 10 & 9 & 5 \\
\hline S-me $5 \times \mathrm{em} 51$ & 10 & 8 & 5 \\
\hline S-me7xem6 & 10 & 9 & 5 \\
\hline S-me $7 \times$ em 7 & 7 & 8 & 4 \\
\hline S-me $8 \times$ em 2 & 10 & 8 & 2 \\
\hline S-me9×GA18 & 10 & 7 & 5 \\
\hline S-me10xem9 & 9 & 9 & 4 \\
\hline S-me22×em 18 & 10 & 10 & 3 \\
\hline S-me23×GA18 & 9 & 5 & 5 \\
\hline S-me $52 \times \mathrm{em} 5$ & 10 & 10 & 2 \\
\hline S-PM8 $8 \times \mathrm{em} 10$ & 10 & 9 & 6 \\
\hline S-GA1 & 10 & 10 & 3 \\
\hline
\end{tabular}

${ }^{1}$ According to the heat tolerance ranking from high to low, three groups of materials were chosen: heat-tolerant group

[1st to 11th, except J23 (6th)], medium group [28th to 48th, except J25 (44th)], and heat-sensitive group (75th-84th).

The total number of bands amplified by 12 SCAR markers in each material was also counted. The materials with no or few bands ( $\leq 2$ ) were J28 (0), J78 (2), J49 (0), J71 (0), J48 (0), J72 (1) and J51 (0), and their HT ranking was in order of the 57th, 73rd, 74th, 76th, 77th, 81st and 83rd. Obviously, most of them had poor HT, which was consistent with the results of band amplification. It could be seen that the 12 SCAR markers developed had high accuracy in the identification of heat-sensitive materials, and the fewer bands, the more heat sensitivity.

In addition, the five materials not identified for HT before were also amplified by the 12 SCAR markers (Figure 3): X1 and X5 amplified all 12 bands, X2, X3, and X4 amplified 6, 8, and 10 bands, respectively. Presumably, their HT from strong to weak was X1/X5, X4, X3, X2; of course, this had yet to be verified after the HT identification of these materials.

\section{Discussion}

HT identification is the most basic, critical and difficult part in the HT researches. In some studies, agronomic traits or physiological and biochemical indicators related to HT were used as criteria for HT identification (Said et al., 2015; El-Rawy and Youssef, 2014; Sun et al., 2015a; Jespersen $e t$ al., 2018; Priya et al., 2018). In this study, plant appearance (yellow leaves) was taken as the only criterion to evaluate the HT of plants, which could more directly reflect the stress degree of plants and facilitate large-scale identification. And, during heat stress, various measures had been taken as far as possible to ensure that about a thousand plants could be exposed to uniform environmental factors (temperature, light, wind speed etc.). At the same time, the selection of individual plants for marker screening was also very cautious, first select the materials according to the average performance of individual plants in the material, and then from each of these materials to select the most extreme individual plants. Individual plants could be easily detected and removed if they exhibited exceptional HT due to chance factors.

As a complex trait, HT is the result of a large number of genes acting together. Different stress environments and different materials may involve different heat resistance mechanisms (Sun et al., 2015b). Meanwhile, screening for molecular markers related to HT is also a matter of chance, such as the number and 
type of markers would affect the results. In tall fescue, Sun et al. (2015a) placed 100 diverse accessions in greenhouse and growth chamber for thermal stress, and screened SSR markers related to HT, respectively. 97 and 67 marker alleles associated with HT related traits were identified in the two trials, but only 2 SSR marker alleles were consistent. In addition, SRAP markers related to drought and heat tolerance were evaluated in wheat, and only the specific bands for drought tolerance were found (El-Rawy and Youssef, 2014). In this study, some heat-sensitive plants sometimes had HT bands, probably because their heat sensitivity was related to the absence of some other heat-tolerant genes, which were not associated with these bands. Similarly, several heattolerant plants did not amplify some HT bands, and their HT might be independent of the heat-tolerant genes associated with these bands. Therefore, it was the right choice to relax the selection criteria of HT bands in this study.

Due to the reproductive characteristics of KBG, the genetic background of each individual plant in a material is not completely consistent. In this study, single plant DNA was used for molecular markers screening, while multiple individual plants mixed DNA in this material was used for SCAR marker validation. As long as one strain DNA could amplify the band, the mixed DNA of this material would do so. This might be why, in SCAR validation, more than the expected number of bands was amplified in the materials of heat-sensitive group and medium group. To test this idea, we looked at three individual plants (J06, J27, and J42) in the HTP, as they sometimes failed to amplify HT bands. In the subsequent amplification with 12 SCAR primers, HT bands were all amplified in the three materials' mixed DNA, which confirmed our suspicions. Thankfully, the results showed these developed SCAR markers had high identification efficiency for heat-sensitive materials. For example, the occurrence rate of S-me $8 \times \mathrm{em} 2$ and $S$-me $52 \times \mathrm{em} 5$ markers in the 15 most heat-sensitive materials was both only $13 \%$. Of course, further verification will be carried out in individual plants within the material to assess the correlation between these SCAR markers and HT.

We would also like to know what information was contained in these obtained HT related fragments, and whether they could help us find more HT genes. Therefore, the amplified sequences of 12 SCAR markers were compared with NCBI (National Center for Biotechnology Information) database, and the plant sequence information (Query Cover > 50\%) was sorted out (Table S3). No homologous sequences were found in the 5

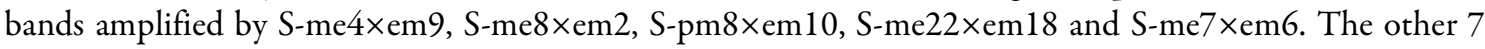
fragments had higher homolog with Brachypodium distachyon, Oryza sativa, Aegilops tauschii, Triticum aestivum, Hordeum vulgare and so on. Unfortunately, none of these fragment comments was directly related to HT.

Using molecular markers, screening genes related to HT in the large and complex genome of KBG is like looking for a needle in a haystack. Is there a better way to screen with greater efficiency? In many crops it was common to use two materials with significant differences in resistance to construct isolated populations and map the linkage map with high saturation. Then, QTL mapping of resistance traits could be carried out to find out the genes location and the relevant molecular markers that caused the difference of resistance between the two materials. However, due to the complex genetic background and reproductive mode of KBG, it was difficult to establish isolated populations for genetic map construction, so no research reports in this field have been found so far.

With the popularity of transcriptome sequencing, some studies began to seek and develop molecular markers related to resistance from transcriptome information. This could greatly increase the number of molecular markers that directly target genes, particularly in species with unclear and/or complex genetic backgrounds. Recently, some work on that has been reported in the grass. For example, in Miscanthus, Nie et al. (2017) developed SSR markers associated to drought tolerance by transcriptome sequencing. Similarly, Zhu et al. (2017) developed SSR markers related to drought stress based on RNA-Seq in Sudan grass (Sorghum sudanense). In orchardgrass (Dactylis glomerata L.), a cool-season grass, Huang et al. (2015) identified differentially expressed genes under heat stress and developed SNP and SSR markers through transcriptome 
analysis. We have just completed the transcriptome sequencing of two KBG ecotypes (J29 and X4) in response to heat stress (Li et al., 2019), and the development and of SSR markers related to HT are under way.

\section{Conclusions}

In this study, the HT of nearly $1000 \mathrm{KBG}$ plants from 84 materials was identified. Through the screening of a large number of SSR and SRAP markers, we developed 12 SCAR markers related to HT, among which S-me $8 \times \mathrm{em} 2$ and S-me $52 \times \mathrm{em} 5$ had the highest identification efficiency. The appearing probability of these two amplification bands was very low in the most heat-sensitive materials. However, the amplified sequences of 12 SCAR markers were not found to be homologous with known heat-tolerant genes.

\section{Acknowledgements}

This work was funded by the National Natural Science Foundation of China (No.31502002) and the Key Project of Shanghai Municipal Agricultural Commission (2013 No.1-1)

\section{Conflict of Interests}

The authors declare that there are no conflicts of interest related to this article.

\section{References}

Aghaei Z, Talebi M, Rahimmalek M (2017). Assessment of genetic diversity within and among sage (Salvia) species using SRAP markers. Plant Genetic Resources 15(3):279-282. https://doiorg/10.1017/S1479262115000593

Akkaya MS, Bhagwat AA, Cregan PB (1992). Length polymorphisms of simple sequence repeat DNA in soybean. Genetics 132:1131-1139.

Budak H, Shearman RC, Gaussoin RE, Dweikat I (2004a). Application of sequence-related amplified polymorphism markers for characterization of turfgrass species. HortScience 39(5):955-958. https://doi.org/10.21273/HORTSCI.39.5.955

Budak H, Shearman RC, Parmaksiz I, Gaussoin RE, Riordan TP, Dweikat I (2004b). Molecular characterization of buffalograss germplasm using sequence-related amplified polymorphism markers. Theoretical and Applied Genetics 108:328-334. https://doi.org/10.1007/s00122-003-1428-4

Clark MS (1997). Plant molecular biology: A laboratory manual. Springer-Verlag, Berlin Heidelberg pp 8-9.

El-Rawy MAE, Youssef M (2014). Evaluation of drought and heat tolerance in wheat based on seedling traits and molecular analysis. Journal of Crop Science and Biotechnology 17(3):183-189. https://doiorg/10.1007/s12892-014-0053-x

Ferriol M, Pico B, Nuez F (2003). Genetic diversity of a germplasm collection of Cucubita pepo using SRAP and AFLP markers. Theoretical and Applied Genetics 107:271-282. https://doi.org/10.1007/s00122-003-1242-z

Gan L, Di R, Chao YH, Han LB, Chen XW, Wu C, Yin SX (2016). De novo transcriptome analysis for Kentucky bluegrass dwarf mutants induced by space mutation. PLoS One 11(5):e0151768. https://doi.org/10.1371/journal.pone.0151768

Guo YW, Wu YQ, Anderson JA, Moss JQ, Zhu L, Fu JM (2017). SSR marker development, linkage mapping, and QTL analysis for establishment rate in common bermudagrass. The Plant Genome 10(1):1-11. https://doi.org/10.3835/plantgenome2016.07.0074

Hansen J, Sato M, Ruedy R, Lo K, Lea DW, Medina-Elizade M (2006). Global temperature change. Proceedings of the National Academy of Science 103(39):14288-14293. https://doi.org/10.1073/pnas.0606291103 
Honig JA, Bonos SA, Meyer WA (2010). Isolation and characterization of 88 polymorphic microsatellite markers in Kentucky bluegrass (Poa pratensis L.). HortScience 45(11):1759-1763. https://doi.org/10.21273/HORTSCI.45.11.1759

Honig JA, Kubik C, Averello V, Vaiciunas J, Meyer WA, Bonos SA (2016). Classification of bentgrass (Agrostis) cultivars and accessions based on microsatellite (SSR) markers. Genetic Resources and Crop Evolution 63:1139-1160. https://doi.org/10.1007/s10722-015-0307-6

Huang LK, Zhang XQ, Xie WG, ZhangJ, Cheng L, Yan HD (2012). Molecular diversity and population structure of the forage grass Hemarthria compressa (Poaceae) in south China based on SRAP markers. Genetics and Molecular Research 11(3):2441-2450. https://doi.org/10.4238/2012.may.24.3

Huang LK, Yan HD, Zhao XX, Zhang XQ, WangJ, Frazier T, ... Liu W (2015). Identifying differentially expressed genes under heat stress and developing molecular markers in orchardgrass (Dactylis glomerata L.) through transcriptome analysis. Molecular Ecology Resources 15:1497-1509. https://doi.org/10.1111/1755-0998.12418

Huang Z, Zhang XX, Jiang SH, Qin MF, Zhao N, Lang LN, ... Xu AX (2017). Analysis of cold resistance and identification of SSR markers linked to cold resistance genes in Brassica rapa L. Breeding Science 67(3):213-220. https://doi.org/10.1270/jsbbs.16161

Jespersen D, Ma XQ, Bonos SA, Belanger FC, Raymer P, Huang BR (2018). Association of SSR and candidate gene markers with genetic variations in summer heat and drought performance for creeping bentgrass. Crop Science 58:2644-2656. https://doi.org/10.2135/cropsci2018.05.0299

Karl TR, Kukla G, Razuvayev VN, Changery MJ, Quayle RG, Heim RR, ... Fu CB (1991). Global warming: Evidence for asymmetric diurnal temperature change. Geophysical Research Letters 18(12):2253-2256. https://doi.org/10.1029/91GL02900

Kempf K, Malisch CS, Grieder C, Widmer F, Kölliker R (2017). Marker-trait association analysis for agronomic and compositional traits in sainfoin (Onobrychis viciifolia). Genetics and Molecular Research 16 (1):gmr16019483. https://doi.org/10.4238/gmr16019483

Kozub PC, Barboza K, Cavagnaro JB, Cavagnaro PF (2018). Development and characterization of SSR markers for Trichloris crinita using sequence data from related grass species. Revista de la Facultad de Ciencias Agrarias 50(1):1-16.

Li G, Quiros CF (2001). Sequence-related amplified polymorphism (SRAP), a new marker system based on a simple PCR reaction: its application to mapping and gene tagging in Brassica. Theoretical and Applied Genetics 103:455-461. https://doi.org/10.1007/s001220100570

Li G, Gao M, Yang B, Quiros CF (2003). Gene for gene alignment between the Brassica and Arabidopsis genomes by direct transcriptome mapping. Theoretical and Applied Genetics 107:168-180. https://doi.org/10.1007/s00122-003-1236-x

Li Q, He YL, Tu MY, Yan JH, Yu LL, Qi WW, Yuan XJ (2019). Transcriptome sequencing of two Kentucky bluegrass (Poa pratensis L.) genotypes in response to heat Stress. Notulae Botanicae Horti Agrobotanici Cluj-Napoca 47(2):328-338. https://doi.org/10.15835/nbha47111365

Meyer WA, Hoffman L, Bonos SA (2017). Breeding cool-season turfgrass cultivars for stress tolerance and sustainability in a changing environment. International Turfgrass Society Research Journal 13:3-10. https://doi.org/10.2134/itsri2016.09.0806

Molla KA, Debnath AB, Ganie SA, Mondal TK (2015). Identification and analysis of novel salt responsive candidate gene based SSRs (cgSSRs) from rice (Oryza sativa L.). BMC Plant Biology 15:122. https://doi.org/10.1186/s12870-015-0498-1

Moustafa KA, Saleh M, Al-Doss AA, Elshafei AA, Salem AK, Al-Qurainy FH, Barakat MN (2014). Identification of TRAP and SRAP markers linked with yield components under drought stress in wheat (Triticum aestivum L.). Plant Omics Journal 7(4):253-259.

Nie G, Tang L, Zhang YJ, Huang LK, Ma X, Cao X, ... Zhang XQ (2017). Development of SSR markers based on transcriptome sequencing and association analysis with drought tolerance in perennial grass Miscanthus from China. Frontiers in Plant Science 8:801. https://doi.org/10.3389/fpls.2017.00801

Paran I, Michelmore RW (1993). Development of reliable PCR-based markers linked to downy mildew resistance genes in lettuce. Theoretical and Applied Genetics 85:985-993. https://doi.org/10.1007/BF00215038

Priya M, Siddique KHM, Dhankhar OP, Prasad PVV, Rao BH, Nair RM, Nayyar H (2018). Molecular breeding approaches involving physiological and reproductive traits for heat tolerance in food crops. Indian Journal of Plant Physiology 23(4):697-720. https://doi.org/10.1007/s40502-018-0427-z 
Reddy INBL, Kim SM, Kim BK, Yoon IS, Kwon TR (2017). Identification of rice accessions associated with $\mathrm{K}^{+} / \mathrm{Na}^{+}$ratio and salt tolerance based on physiological and molecular responses. Rice Science 24(6):360-364. https://doi.org/10.1016/j.rsci.2017.10.002

Said AA, Hamada A, Youssef M (2015). Assessment of heat tolerance in bread wheat using some agronomic traits and SRAP markers. Egyptian Journal of Plant Breeding 19(3):979-994. https://doi.org/10.12816/0031573

Sun XY, Du ZM, Ren J, Amombo E, Hu T, Fu JM (2015a). Association of SSR markers with functional traits from heat stress in diverse tall fescue accessions. BMC Plant Biology 15:116. https://doi.org/10.1186/s12870-015-0494-5

Sun XY, Xie Y, Bi YF, Liu JP, Amombo E, Hu T, Fu JM (2015b). Comparative study of diversity based on heat tolerant-related morpho-physiological traits and molecular markers in tall fescue accessions. Scientific Reports 5:18213. https://doi.org/10.1038/srep18213

Vos P, Hogers R, Bleeker M, Reijans M, van de Lee T, Hornes M, .. Z Zabeau M (1995). AFLP: a new technique for DNA fingerprinting. Nucleic Acids Research 23(21): 4407-4414. https://doi.org/10.1093/nar/23.21.4407

Wang G, Pan JS, Li XZ, He HL, Wu AZ, Cai R (2005). Construction of a cucumber genetic linkage map with SRAP markers and location of the genes for lateral branch traits. Science in China Series C: Life Sciences 48(3):213-220. https://doi.org/10.1007/BF03183614

Wang ZY, Liao L, Yuan XJ, Guo A, Liu JX (2011). Genetic relationships of bermudagrass (Cynodon dactylon var. dactylon) from different countries revealed by sequence-related amplified polymorphism (SRAP) analysis. African Journal of Biotechnology 10(75):17106-17115. https://doi.org/10.5897/ajb11.1422

Williams JG, Kubelik AR, Livak KJ, Rafalski JA, Tingey SV (1990). DNA polymorphisms amplified by arbitrary primes are useful as genetic markers. Nucleic Acids Research 18(22):6531-6535. https://doi.org/10.1093/nar/18.22.6531

Yuan XJ, Tu MY, He YL, Wang WQ, Li J, Zhou SM (2018). Analysis of genetic diversity in 73 Kentucky bluegrass materials by SSR and SRAP Markers. Notulae Botanicae Horti Agrobotanici Cluj-Napoca 46(2):327-335. https://doi.org/10.15835/nbha46210916

Zheng YQ, Xu SJ, Liu J, Zhao Y, Liu JX (2017). Genetic diversity and population structure of Chinese natural bermudagrass [Cynodon dactylon (L.) Pers.] germplasm based on SRAP markers. PLoS One 12(5): e0177508. https://doi.org/10.1371/journal.pone.0177508

Zhu YQ, Wang X, Huang LK, Lin CW, Zhang XQ, Xu WZ, .. Peng DD (2017). Transcriptomic identification of droughtrelated genes and SSR markers in Sudan grass based on RNA-Seq. Frontiers in Plant Science 8:687. https://doi.org/10.3389/fpls.2017.01518 
Tu M et al. (2020). Not Bot Horti Agrobo 48(2):509-522

OPEN ACCESS

(c) (i)

The journal offers free, immediate, and unrestricted access to peer-reviewed research and scholarly work. Users are allowed to read, download, copy, distribute, print, search, or link to the full texts of the articles, or use them for any other lawful purpose, without asking prior permission from the publisher or the author.

License - Articles published in Notulae Botanicae Horti Agrobotanici Cluj-Napoca are Open-Access, distributed under the terms and conditions of the Creative Commons Attribution (CC BY 4.0) License.

(c) Articles by the authors; UASVM, Cluj-Napoca, Romania. The journal allows the author(s) to hold the copyright/to retain publishing rights without restriction. 
Table S1. Background of the Kentucky bluegrass materials

Supplementary Files

Table S2. List of SRAP primers used in the present study

Table S3. The homologous plant fragment information compared with the amplified sequences of 12 SCAR primer pairs (by NCBI database)

Figure S1. UPGMA cluster analysis $(12+12)$ based on polymorphic band types and heat tolerance trait

Table S1. Background of the Kentucky bluegrass materials

\begin{tabular}{|c|c|c|c|c|c|c|c|}
\hline $\mathrm{J} \mathrm{Code}^{1}$ & Z Code ${ }^{2}$ & $\begin{array}{c}\text { Commercial } \\
\text { name or } \\
\text { Place of origin }\end{array}$ & Types $^{3}$ & $\mathrm{~J} \mathrm{Code}^{1}$ & Z Code ${ }^{2}$ & $\begin{array}{c}\text { Commercial name } \\
\text { or } \\
\text { Place of origin }\end{array}$ & Types $^{3}$ \\
\hline J01 & Z01 & Odyssey & $\begin{array}{l}\text { Imported } \\
\text { variety }\end{array}$ & J46 & $\mathrm{Z} 45$ & Tianzhul & $\begin{array}{c}\text { Domestic wild } \\
\text { material }\end{array}$ \\
\hline $\mathrm{J} 02$ & Z02 & Freedom III & $\begin{array}{c}\text { Imported } \\
\text { variety }\end{array}$ & $\mathrm{J} 47$ & $\mathrm{Z} 46$ & Qibian & $\begin{array}{c}\text { Domestic wild } \\
\text { material }\end{array}$ \\
\hline J03 & $\mathrm{Z} 03$ & Everest & $\begin{array}{c}\text { Imported } \\
\text { variety }\end{array}$ & $\mathrm{J} 48$ & - & $\mathrm{Aba}$ & $\begin{array}{c}\text { Domestic wild } \\
\text { material }\end{array}$ \\
\hline J04 & Z04 & Arcadia & $\begin{array}{l}\text { Imported } \\
\text { variety }\end{array}$ & J49 & - & Gulang & $\begin{array}{c}\text { Domestic wild } \\
\text { material }\end{array}$ \\
\hline $\mathrm{J} 05$ & $\mathrm{Z} 05$ & Nuglade & $\begin{array}{l}\text { Imported } \\
\text { variety }\end{array}$ & $\mathrm{J} 50$ & - & Gansu & $\begin{array}{c}\text { Domestic wild } \\
\text { material }\end{array}$ \\
\hline J06 & Z06 & Award & $\begin{array}{l}\text { Imported } \\
\text { variety }\end{array}$ & $\mathrm{J} 51$ & - & Lushan & $\begin{array}{c}\text { Domestic wild } \\
\text { material }\end{array}$ \\
\hline J07 & $\mathrm{Z} 07$ & Nassau & $\begin{array}{l}\text { Imported } \\
\text { variety }\end{array}$ & $\mathrm{J} 52$ & Z47 & Tianzhu2 & $\begin{array}{c}\text { Domestic wild } \\
\text { material }\end{array}$ \\
\hline J08 & Z08 & Classic & $\begin{array}{l}\text { Imported } \\
\text { variety }\end{array}$ & $\mathrm{J} 53$ & - & Luqu1 & $\begin{array}{c}\text { Domestic wild } \\
\text { material }\end{array}$ \\
\hline J09 & Z09 & Blue Chip & $\begin{array}{c}\text { Imported } \\
\text { variety }\end{array}$ & $\mathrm{J} 54$ & Z48 & Midnight 2 & $\begin{array}{c}\text { Imported } \\
\text { variety }\end{array}$ \\
\hline $\mathrm{J} 10$ & $\mathrm{Z} 10$ & Kingdom & $\begin{array}{c}\text { Imported } \\
\text { variety }\end{array}$ & $\mathrm{J} 55$ & Z49 & Brilliant & $\begin{array}{c}\text { Imported } \\
\text { variety }\end{array}$ \\
\hline $\mathrm{J} 11$ & $\mathrm{Z} 11$ & Barrister & $\begin{array}{l}\text { Imported } \\
\text { variety }\end{array}$ & $\mathrm{J} 56$ & $\mathrm{Z} 50$ & Merit & $\begin{array}{l}\text { Imported } \\
\text { variety }\end{array}$ \\
\hline $\mathrm{J} 12$ & $\mathrm{Z} 12$ & Baron & $\begin{array}{c}\text { Imported } \\
\text { variety }\end{array}$ & $\mathrm{J} 57$ & $\mathrm{Z} 51$ & Kenblue & $\begin{array}{c}\text { Imported } \\
\text { variety }\end{array}$ \\
\hline $\mathrm{J} 13$ & $\mathrm{Z} 13$ & Merit & $\begin{array}{c}\text { Imported } \\
\text { variety }\end{array}$ & $\mathrm{J} 58$ & $\mathrm{Z} 52$ & Miracle & $\begin{array}{c}\text { Imported } \\
\text { variety }\end{array}$ \\
\hline $\mathrm{J} 14$ & $\mathrm{Z} 14$ & Barvictor & $\begin{array}{c}\text { Imported } \\
\text { variety }\end{array}$ & J59 & $\mathrm{Z} 53$ & Numerit & $\begin{array}{l}\text { Imported } \\
\text { variety }\end{array}$ \\
\hline $\mathrm{J} 15$ & $\mathrm{Z} 15$ & Midnight & $\begin{array}{c}\text { Imported } \\
\text { variety }\end{array}$ & $\mathrm{J} 60$ & Z54 & CPP811 (Danmark) & Imported line \\
\hline $\mathrm{J} 16$ & $\mathrm{Z} 16$ & Rugby2 & $\begin{array}{c}\text { Imported } \\
\text { variety }\end{array}$ & $\mathrm{J} 61$ & $\mathrm{Z} 55$ & CPP812 (Danmark) & Imported line \\
\hline $\mathrm{J} 17$ & $\mathrm{Z} 17$ & Abbey & $\begin{array}{c}\text { Imported } \\
\text { variety }\end{array}$ & $\mathrm{J} 62$ & $\mathrm{Z} 56$ & Allure & $\begin{array}{c}\text { Imported } \\
\text { variety }\end{array}$ \\
\hline $\mathrm{J} 18$ & $\mathrm{Z} 18$ & Sapphire & $\begin{array}{l}\text { Imported } \\
\text { variety }\end{array}$ & $\mathrm{J} 63$ & $\mathrm{Z} 57$ & Harmony & $\begin{array}{c}\text { Imported } \\
\text { variety }\end{array}$ \\
\hline J19 & $\mathrm{Z} 19$ & Blue fox & $\begin{array}{c}\text { Imported } \\
\text { variety }\end{array}$ & J64 & - & Songpan & $\begin{array}{c}\text { Domestic wild } \\
\text { material }\end{array}$ \\
\hline $\mathrm{J} 20$ & $\mathrm{Z} 20$ & Park & $\begin{array}{l}\text { Imported } \\
\text { variety }\end{array}$ & $\mathrm{J} 65$ & $\mathrm{Z} 58$ & Dushan & $\begin{array}{c}\text { Domestic wild } \\
\text { material }\end{array}$ \\
\hline $\mathrm{J} 21$ & $\mathrm{Z} 21$ & Kentucky & $\begin{array}{c}\text { Imported } \\
\text { variety }\end{array}$ & J66 & Z59 & Daqingshan & $\begin{array}{c}\text { Domestic } \\
\text { variety }\end{array}$ \\
\hline $\mathrm{J} 22$ & $\mathrm{Z} 22$ & Brooklawn & $\begin{array}{c}\text { Imported } \\
\text { variety }\end{array}$ & $\mathrm{J} 67$ & $\mathrm{Z} 60$ & Qinghai & $\begin{array}{c}\text { Domestic wild } \\
\text { material }\end{array}$ \\
\hline $\mathrm{J} 23$ & $\mathrm{Z} 23$ & Bedazzled & $\begin{array}{c}\text { Imported } \\
\text { variety }\end{array}$ & $\mathrm{J} 68$ & $\mathrm{Z} 61$ & Changlin & $\begin{array}{c}\text { Domestic wild } \\
\text { material }\end{array}$ \\
\hline $\mathrm{J} 24$ & $\mathrm{Z} 24$ & Nublue & $\begin{array}{l}\text { Imported } \\
\text { variety }\end{array}$ & $\mathrm{J} 69$ & - & Maqu & $\begin{array}{c}\text { Domestic wild } \\
\text { material }\end{array}$ \\
\hline $\mathrm{J} 25$ & - & Yongji & $\begin{array}{c}\text { Domestic wild } \\
\text { material }\end{array}$ & $\mathrm{J} 70$ & - & Hongyuan & $\begin{array}{c}\text { Domestic wild } \\
\text { material }\end{array}$ \\
\hline $\mathrm{J} 26$ & $\mathrm{Z} 25$ & Avanlanche & $\begin{array}{l}\text { Imported } \\
\text { variety }\end{array}$ & $\mathrm{J} 71$ & - & Maerkang & $\begin{array}{c}\text { Domestic wild } \\
\text { material }\end{array}$ \\
\hline $\mathrm{J} 27$ & $\mathrm{Z} 26$ & Huhe & $\begin{array}{l}\text { Domestic } \\
\text { variety }\end{array}$ & $\mathrm{J} 72$ & - & Heishui & $\begin{array}{c}\text { Domestic wild } \\
\text { material }\end{array}$ \\
\hline
\end{tabular}




\begin{tabular}{|c|c|c|c|c|c|c|c|}
\hline $\mathrm{J} 28$ & $\mathrm{Z} 27$ & Jilin & $\begin{array}{c}\text { Domestic wild } \\
\text { material }\end{array}$ & $\mathrm{J} 73$ & $\mathrm{Z} 62$ & Russial & $\begin{array}{c}\text { Wild material } \\
\text { abroad }\end{array}$ \\
\hline J29 & $\mathrm{Z} 28$ & KBG03 & $\begin{array}{c}\text { Domestic } \\
\text { variety }\end{array}$ & $\mathrm{J} 74$ & - & Czechoslovakian & $\begin{array}{c}\text { Wild material } \\
\text { abroad }\end{array}$ \\
\hline $\mathrm{J} 30$ & Z29 & KBG04 & $\begin{array}{c}\text { Domestic } \\
\text { variety }\end{array}$ & $\mathrm{J} 75$ & - & Denmark & $\begin{array}{l}\text { Wild material } \\
\text { abroad }\end{array}$ \\
\hline $\mathrm{J} 31$ & $\mathrm{Z} 30$ & Evergreen & $\begin{array}{c}\text { Imported } \\
\text { variety }\end{array}$ & $\mathrm{J} 76$ & $\mathrm{Z} 63$ & Russia2 & $\begin{array}{c}\text { Wild material } \\
\text { abroad }\end{array}$ \\
\hline $\mathrm{J} 32$ & $\mathrm{Z} 31$ & $\mathrm{Nu}$ destiny & $\begin{array}{c}\text { Imported } \\
\text { variety }\end{array}$ & $\mathrm{J} 77$ & $\mathrm{Z} 64$ & Kazakhstan1 & $\begin{array}{c}\text { Wild material } \\
\text { abroad }\end{array}$ \\
\hline $\mathrm{J} 33$ & $\mathrm{Z} 32$ & Superglade & $\begin{array}{c}\text { Imported } \\
\text { variety }\end{array}$ & $\mathrm{J} 78$ & $\mathrm{Z} 65$ & Kazakhstan2 & $\begin{array}{c}\text { Wild material } \\
\text { abroad }\end{array}$ \\
\hline $\mathrm{J} 34$ & $\mathrm{Z} 33$ & Blueberry & $\begin{array}{c}\text { Imported } \\
\text { variety }\end{array}$ & $\mathrm{J} 79$ & $\mathrm{Z} 66$ & Kazakhstan3 & $\begin{array}{c}\text { Wild material } \\
\text { abroad }\end{array}$ \\
\hline $\mathrm{J} 35$ & Z34 & $\begin{array}{l}\text { Gourment } \\
\text { Midnight }\end{array}$ & $\begin{array}{c}\text { Imported } \\
\text { variety }\end{array}$ & $\mathrm{J} 80$ & $\mathrm{Z} 67$ & Russia3 & $\begin{array}{c}\text { Wild material } \\
\text { abroad }\end{array}$ \\
\hline $\mathrm{J} 36$ & $\mathrm{Z} 35$ & B6 & $\begin{array}{c}\text { Imported } \\
\text { variety }\end{array}$ & $\mathrm{J} 81$ & $\mathrm{Z} 68$ & Kazakhstan 4 & $\begin{array}{c}\text { Wild material } \\
\text { abroad }\end{array}$ \\
\hline $\mathrm{J} 37$ & $\mathrm{Z} 36$ & Jumpstart & $\begin{array}{c}\text { Imported } \\
\text { variety }\end{array}$ & J82 & Z69 & Russia4 & $\begin{array}{c}\text { Wild material } \\
\text { abroad }\end{array}$ \\
\hline $\mathrm{J} 38$ & $\mathrm{Z} 37$ & Liberator & $\begin{array}{c}\text { Imported } \\
\text { variety }\end{array}$ & $\mathrm{J} 83$ & $\mathrm{Z} 70$ & America & $\begin{array}{c}\text { Wild material } \\
\text { abroad }\end{array}$ \\
\hline J39 & $\mathrm{Z} 38$ & Moonnight & $\begin{array}{c}\text { Imported } \\
\text { variety }\end{array}$ & J84 & $\mathrm{Z} 71$ & Russia5 & $\begin{array}{c}\text { Wild material } \\
\text { abroad }\end{array}$ \\
\hline $\mathrm{J} 40$ & Z39 & Right & $\begin{array}{c}\text { Imported } \\
\text { variety }\end{array}$ & $\mathrm{X} 1$ & - & Thermal blue & $\begin{array}{c}\text { Imported } \\
\text { variety }\end{array}$ \\
\hline J41 & $\mathrm{Z} 40$ & 4-season & $\begin{array}{l}\text { Imported } \\
\text { variety }\end{array}$ & $\mathrm{X} 2$ & - & Luqu2 & $\begin{array}{c}\text { Domestic wild } \\
\text { material }\end{array}$ \\
\hline $\mathrm{J} 42$ & $\mathrm{Z} 41$ & bright & $\begin{array}{c}\text { Imported } \\
\text { variety }\end{array}$ & $\mathrm{X} 3$ & - & Xiahe & $\begin{array}{c}\text { Domestic wild } \\
\text { material }\end{array}$ \\
\hline $\mathrm{J} 43$ & $\mathrm{Z} 42$ & Zahe & $\begin{array}{c}\text { Domestic } \\
\text { variety }\end{array}$ & $\mathrm{X} 4$ & $\mathrm{Z} 72$ & Ninglan & $\begin{array}{c}\text { Domestic wild } \\
\text { material }\end{array}$ \\
\hline J44 & Z43 & Nublue & $\begin{array}{c}\text { Imported } \\
\text { variety }\end{array}$ & $\mathrm{X} 5$ & $\mathrm{Z} 73$ & Langra & $\begin{array}{c}\text { Imported } \\
\text { variety }\end{array}$ \\
\hline $\mathrm{J} 45$ & Z44 & Lanzhou & $\begin{array}{c}\text { Domestic wild } \\
\text { material }\end{array}$ & & & & \\
\hline
\end{tabular}

${ }^{1}$ Materials of J25, J29, J45-J87 came from State Medium-term Repository for Grass Germplasms, China

${ }^{2} \mathrm{The} \mathrm{Z}$ code was the number of materials in the reference (Yuan et al., 2018)

${ }^{3}$ Imported varieties were distributed by: Beijing Bright Turf \& Forage Co., Ltd.; Beijing Barenbrug International Co., Ltd.; Beijing Clover Turf \& Forage Co., Ltd. and Beijing TopGreen Seed Co., Ltd. Domestic wild materials are named after their collection sites in China. Wild materials abroad named after the country of origin.

Table S2. List of SRAP primers used in the present study

\begin{tabular}{|c|c|c|c|}
\hline Forward primer & Sequence $\left(5^{\prime}->3^{\prime}\right)$ & Reverse primer & Sequence $\left(5^{\prime}->3^{\prime}\right)$ \\
\hline me1 & TGAGTCCAAACCGGATA & em 1 & GACTGCGTACGAATTAAT \\
\hline me2 & TGAGTCCAAACCGGAGC & em 2 & GACTGCGTACGAATTTGC \\
\hline me3 & TGAGTCCAAACCGGAAT & em 3 & GACTGCGTACGAATTGAC \\
\hline me4 & TGAGTCCAAACCGGACC & em 4 & GACTGCGTACGAATTTGA \\
\hline me5 & TGAGTCCAAACCGGAAG & em 5 & GACTGCGTACGAATTAAC \\
\hline me6 & TGAGTCCAAACCGGACA & em 6 & GACTGCGTACGAATTGCA \\
\hline me7 & TGAGTCCAAACCGGTGC & em 7 & GACTGCGTACGAATTCAA \\
\hline me8 & TGAGTCCAAACCGGTAG & em 8 & GACTGCGTACGAATTCTG \\
\hline me9 10 & TGAGTCCAAACCGGCAG & em 9 & GACTGCGTACGAATTTCA \\
\hline me1 & TGAGTCCAAACCGGCAT & em 10 & GACTGCGTACGAATTGAG \\
\hline me52 & TGAGTCCAAACCGGTCT & em51 & GACTGCGTACGAATTGAT \\
\hline me53 & TGAGTCCTTTCCGGTCC & em 18 & GACTGCGTACGAATTCAG \\
\hline me54 & TGAGTCCTTTCCGGTGC & OD3 & CCAAAACCTAAAACCAGG \\
& & & A \\
\hline
\end{tabular}




\begin{tabular}{|c|c|c|c|}
\hline me21 & TGAGTCGTATCCGGTCT & SA4 & $\begin{array}{c}\text { TTCTTCTTCCTGGACACAA } \\
\text { A }\end{array}$ \\
\hline me22 & TGAGTCGTATCCGGAGT & GA18 & $\begin{array}{c}\text { GGCTTGAACGAGTGACTG } \\
\text { A }\end{array}$ \\
\hline me23 & TGAGTCGTATCCGGTAG & & \\
\hline DC1 & TAAACAATGGCTACTCAAG & & \\
\hline PM8 & CTGGTGAATGCCGCTCT & & \\
\hline
\end{tabular}

A)

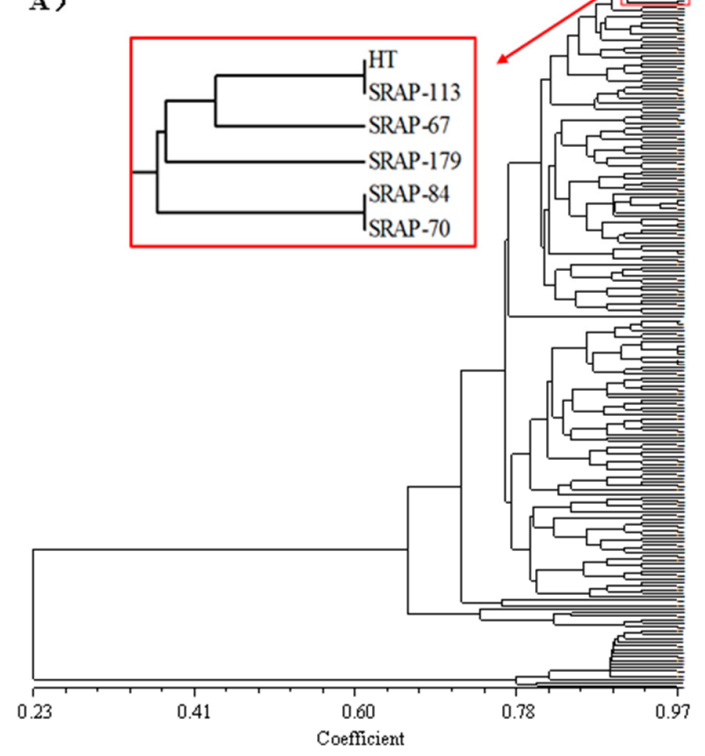

B)

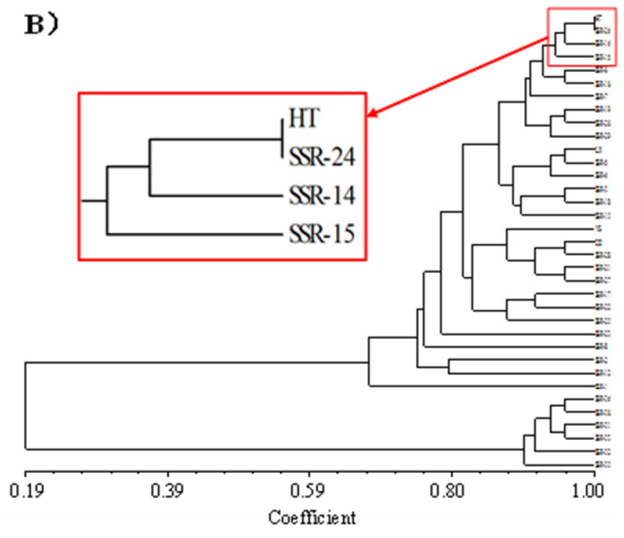

Figure S1. UPGMA cluster analysis $(12+12)$ based on polymorphic band types and heat tolerance trait. (A) 186 SRAP band types + HT. (B) 31 SSR band types + HT. HT, heat tolerance trait 